\title{
В.І. Клименко
}

\section{ВПЛИВ ТРИВАЛОЇ ТЕРАПІЇ СТАТИНАМИ НА МІКРОЕЛЕМЕНТНИЙ ОБМІН У ХВОРИХ НА ІШЕМІЧНУ ХВОРОБУ СЕРЦЯ}

ДВНЗ «Івано-Франківський національний медичний університет»

Резюме. У 66 хворих на стабільну стенокардію (CC) вивчено зміни мікроелементного обміну та показники інструментальних методів обстеження залежно від рівня в крові загального холестерину під час тривалої ліпідзнижувальної терапії. Показано неоднозначні зміни мікроелементного обміну, показників внутріш- ньосерцевої гемодинаміки та толерантності до фізичного навантаження на тлі терапії статинами.

Ключові слова: ішемічна хвороба серця, статини, мікроелементи.

боку, призводить до порушення тканинного дихання, а з іншого - активації каталази, показника антиоксидантного захисту. Свідченням підвищення інтенсивності перекисного окиснення ліпідів $є$ зниження вмісту кобальту в осіб із гіперхолестеринемією $[3,6]$.

Із впровадженням у практику тривалої ліпідознижувальної терапії постає потреба вивчення впливу їі на обмін мікроелементів.

Мета дослідження. Вивчити мікроелементний обмін у хворих на IXC за умов тривалого призначення симвастатину та аторвастатину.

Матеріал і методи. Як модель тривалої ліпідзнижувальної терапії обрано 66 хворих на СС, проведення в яких ліпідзнижувальної терапії $\epsilon$ сьогодні існуючим стандартом лікування. Виділено три основні групи пацієнтів. У І групі пацієнтів із нормальним рівнем ЗХС застосовували симвастатин у комплексі стандартної терапії. Особи II групи з підвищеним рівнем 3ХС вживали симвастатин. Особам III групи 3 підвищеним рівнем 3ХС до стандарту лікування було включено аторвастатин.

Аналізували клінічний перебіг захворювання, частоту виникнення нападів стенокардії, кількість вживаних таблеток нітрогліцерину, показники толерантності до фізичних навантажень, стан внутрішньосерцевої гемодинаміки.

Ехокардіографію виконували на апараті SONOACE-4800 ("Medison", Кorea). Вимірювали кінцеві систолічний і діастолічний розміри лівого шлуночка. Вираховували кінцево-діастолічний i кінцево-систолічний об'єми, фракцію викиду (ФВ).

Велоергометрію (ВЕМ) проводили на велоергометрі "Corival” з реєстрацією ЕКГ у 12 загальноприйнятих відведеннях на апараті Heart Screen 112 D за стандартною методикою. У момент припинення навантаження оцінювали порогову потужність навантаження (W), „подвійний добуток” (ПД).

Визначення мікроелементного складу крові (цинк, мідь, залізо, кобальт) проводили на атомно-абсорбційному спектрофотометрі С-115 ПК.

Отримані результати дослідження опрацьовані методами варіаційної статистики з визначенням критерію вірогідності Стьюдента (t). 
Результати дослідження та їх обговорення. У процесі ліпідзнижувальної терапії спостерігали сприятливу динаміку клінічних ознак та показників ЕхоКС у хворих на СС. Ступінь зростання останніх залежав не лише від наявності і вираженості гіперхолестеринемії, але і від обраного ліпідзнижувального засобу. Включення до лікувального комплексу аторвастатину дозволило суттєво оптимізувати скоротливу функцію міокарда (через три місяці терапії аторвастатином ФВ зросла на $11,8 \%, \mathrm{p}<0,01$, проти $9,6 \%, \mathrm{p}<0,05$ за умов застосування симвастатину).

Оцінюючи показники ВЕМ на тлі терапії симвастатином протягом шести місяців у хворих на $\mathrm{CC}$ із нормальним рівнем 3ХС відсутні вірогідні зміни $\mathrm{W}$ та ПД $(\mathrm{p}>0,5)$. У хворих на $\mathrm{CC}$ iз гіперхолестеринемією, особливо за умов застосування аторвастатину протягом шести місяців, відмічено тенденцію до більш значимого зростання показника $\mathrm{W}, \quad 3 \quad(69,23 \pm 2,08) \quad$ Вт до $(77,70 \pm 4,16)$ Вт, на 11,2 \% проти $10,9 \%$ - при терапії симвастатином ( $\mathrm{p}>0,2)$.

Застосування симвастатину протягом трьох місяців у хворих на СС із нормальним та підвищеним рівнем $3 \mathrm{XC}$, хоча і сприяло зростанню вмісту заліза в крові, проте не призвело до його нормалізації (нормальний вміст заліза в крові $518,7 \pm 10,3$ мг/л, $(\mathrm{p}<0,01))$. Не відмічено вірогідного зростання вмісту заліза у пацієнтів, які вживали аторвастатин, $\mathrm{p}>0,05$ (табл.).

Спостерігали вірогідне зростання вмісту міді в крові протягом одного місяця лікування із застосуванням статинів у хворих на СС із підвищеним рівнем 3ХС (норма вмісту міді в практично здорових осіб складає 1,327士0,024 мг/л). Включення аторвастатину до стандартної терапії сприяло більш суттєвому підвищенню вмісту міді (на 43,6 \%, проти 37,6 \%) за умов терапії симвастатином $(\mathrm{p}<0,001)$.

Встановлено вірогідний приріст вмісту цинку в крові хворих незалежно від рівня ЗХC $(\mathrm{p}<0,001)$. Однак застосування симвастатину, як i аторвастатину в комплексі стандартної терапії СС протягом одного місяця сприяло значному підвищенню вмісту цинку в крові, що становило $107,4 \%$ та 106,6 \% відповідно, вірогідно перевищуючи рівень здорових осіб, зокрема $6,698 \pm 0,122$ мг/л.

Неоднозначними були зміни вмісту кобальту в крові пацієнтів залежно від рівня 3ХС. Зокрема, суттєве зниження вмісту кобальту спостерігали за умов застосування симвастатину у хворих на $\mathrm{CC}$ iз нормальним рівнем $3 \mathrm{XC}, \mathrm{p}<0,001$ (у нормі вміст кобальту в крові складає 49,7 $\pm 1,7$ мкг/л). У хворих на СС і гіперхолестеринемією у всіх групах осіб спостерігали підвищення вмісту кобальту в крові вище рівня здорових. При цьому, найбільш значиме підвищення вмісту кобальту відмічено за умов застосування аторвастатину, 3

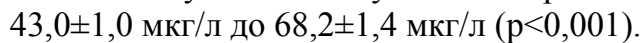

У процесі тривалої ліпідзнижувальної терапії спостерігали покращання показників внутрішньосерцевої гемодинаміки, підвищення толерантності до фізичних навантажень у хворих на СC із гіперхолестеринемією, особливо за умов застосування аторвастатину. Терапія стабільної стенокардії з включенням симвастатину, зокрема, в осіб iз нормальним рівнем 3ХC у крові, недостатньо впливає на клінічний перебіг стабільної стенокардії, стан внутрішньосерцевої гемодинаміки, показники толерантності до фізичних навантажень.

Використання статинів у комплексі стандартної терапії стабільної стенокардії має різний вплив на обмін мікроелементів. Рівень заліза в крові зростає як у осіб із нормальним, так і з підвищеним рівнем $3 \mathrm{XC}$, що, у свою чергу, сприяє покращанню тканинного дихання, усуненню гіпоксії. При цьому, аторвастатин практично не впливає на рівень заліза в крові. У пацієнтів із підвищеним рівнем 3ХС тривала ліпідзнижувальна терапія сприяє не лише нормалізації вмісту міді в крові, але і подальшому утриманню висо-

Таблиця

Динаміка показників мікроелементоного складу плазми крові у хворих на стабільну стенокардію в процесі лікування із застосуванням статинів (M $\pm \mathbf{m})$

\begin{tabular}{|c|c|c|c|c|c|c|c|c|c|}
\hline \multirow{2}{*}{$\begin{array}{l}\text { Показник, } \\
\text { од.виміру }\end{array}$} & \multicolumn{3}{|c|}{$\begin{array}{c}\text { Симвастатин у хворих на СС } \\
\text { із нормальним рівнем } 3 \mathrm{XC} \\
(\mathrm{n}=21) \\
\end{array}$} & \multicolumn{3}{|c|}{$\begin{array}{c}\text { Симвастатин у хворих на СС } \\
\text { підвищеним рівнем 3ХC } \\
(\mathrm{n}=22) \\
\end{array}$} & \multicolumn{3}{|c|}{$\begin{array}{c}\text { Аторвастатин у хворих на СC } \\
\text { підвищеним рівнем 3XC (n=23) }\end{array}$} \\
\hline & $\begin{array}{l}\text { до ліку- } \\
\text { вання }\end{array}$ & $\begin{array}{l}1 \text { мі- } \\
\text { сяць }\end{array}$ & 3 місяці & $\begin{array}{l}\text { до ліку- } \\
\text { вання }\end{array}$ & $\begin{array}{l}1 \text { мі- } \\
\text { сяць }\end{array}$ & 3 місяці & $\begin{array}{l}\text { до ліку } \\
\text {-вання }\end{array}$ & 1 місяць & 3 місяці \\
\hline $\begin{array}{c}\text { Залізо, } \\
\text { мг/л }\end{array}$ & $\begin{array}{c}448,1 \pm \\
9,7\end{array}$ & $\begin{array}{c}472,5 \pm \\
5,1^{*}\end{array}$ & $\begin{array}{c}480,8 \pm \\
5,8 * *\end{array}$ & $\begin{array}{c}415,2 \pm \\
5,9\end{array}$ & $\begin{array}{c}470,6 \pm \\
3,5^{*}\end{array}$ & $\begin{array}{c}485,4 \pm \\
2,7^{*}\end{array}$ & $\begin{array}{c}418,4 \pm \\
5,6\end{array}$ & $\begin{array}{c}430,5 \pm \\
4,9\end{array}$ & $\begin{array}{c}438,2 \pm \\
8,5\end{array}$ \\
\hline $\begin{array}{l}\text { Мідь, } \\
\text { мг/л }\end{array}$ & $\begin{array}{c}1,480 \pm \\
0,025\end{array}$ & $\begin{array}{c}1,520 \pm \\
0,014\end{array}$ & $\begin{array}{c}1,472 \pm \\
0,009\end{array}$ & $\begin{array}{c}1,123 \pm \\
0,023\end{array}$ & $\begin{array}{l}1,545 \pm \\
0,018^{*}\end{array}$ & $\begin{array}{l}1,490 \pm \\
0,015^{*}\end{array}$ & $\begin{array}{c}1,120 \pm \\
0,023\end{array}$ & $\begin{array}{l}1,608 \pm \\
0,013^{*}\end{array}$ & $\begin{array}{l}1,570 \pm \\
0,020^{*}\end{array}$ \\
\hline $\begin{array}{l}\text { Цинк, } \\
\text { мг/л }\end{array}$ & $\begin{array}{c}4,279 \pm \\
0,124\end{array}$ & $\begin{array}{c}6,820 \pm \\
0,069^{*} \\
* *\end{array}$ & $\begin{array}{c}6,930 \pm \\
0,046^{* *} \\
*\end{array}$ & $\begin{array}{c}3,576 \pm \\
0,089\end{array}$ & $\begin{array}{l}7,415 \pm \\
0,069^{*}\end{array}$ & $\begin{array}{l}7,850 \pm \\
0,084^{*}\end{array}$ & $\begin{array}{c}3,581 \pm \\
0,087\end{array}$ & $\begin{array}{l}7,400 \pm \\
0,061^{*}\end{array}$ & $\begin{array}{l}7,580 \pm \\
0,088^{*}\end{array}$ \\
\hline $\begin{array}{l}\text { Кобальт, } \\
\text { мкг/л }\end{array}$ & $\begin{array}{c}67,8 \pm \\
3,0\end{array}$ & $\begin{array}{l}56,2 \pm \\
1,4^{* *}\end{array}$ & $\begin{array}{l}52,8 \pm \\
1,8^{* * *}\end{array}$ & $\begin{array}{c}41,0 \pm \\
1,2\end{array}$ & $\begin{array}{c}58,2 \pm \\
1,1^{*}\end{array}$ & $\begin{array}{c}56,4 \pm \\
1,3^{*}\end{array}$ & $\begin{array}{c}43,0 \pm \\
1,0\end{array}$ & $\begin{array}{c}64,5 \pm \\
1,3^{*}\end{array}$ & $\begin{array}{c}68,2 \pm \\
1,4^{*}\end{array}$ \\
\hline
\end{tabular}

Примітка. Вірогідність різниці показників порівняно з величинами до лікування: * - p<0,05; ** - p<0,01; *** - p<0,001 
ких рівнів цього мікроелемента, таким чином активізуючи окисно-відновні процеси. Однак не відмічено суттєвого впливу симвастатину на рівень міді в крові в осіб із нормальним рівнем 3ХC. Констатовано значиме зростання вмісту цинку в крові осіб із нормальним та підвищеним рівнем 3ХС, що перевищує рівень здорових, i свідчить, з одного боку, про підвищення білковосинтетичної функції печінки та покращання іiі депонуючої функції, а з іншого, - схильність таких пацієнтів до коронаротромбозу. Неоднозначні зміни торкаються рівня кобальту в крові, який знижується в осіб із нормальним рівнем $3 \mathrm{XC}$ та підвищується вище рівня здорових за умов гіперхолестеринемії, що, у свою чергу, призводить до пригнічення процесів перекисного окиснення ліпідів.

\section{Висновки}

1. Клінічний перебіг стабільної стенокардії, толерантність до фізичних навантажень та зміни гемодинаміки в осіб із гіперхолестеринемією $є$ більш суттєвими, ніж у осіб із нормальним рівнем загального холестерину в сироватці крові. Неоднозначними у таких осіб є порушення обміну мікроелементів.

2. Тривала ліпідзнижувальна терапія сприяє не лише позитивному клінічному ефекту, але i частково забезпечує корекцію обміну мікроелементів, динаміка яких залежить не лише від наявності гіперхолестеринемії, але і від обраного статину.

Перспективою подальших досліджень 3 вивчення впливу ліпідзнижувальної терапії на мікроелементний обмін у хворих на ішемічну хворобу серця є проведення довготривалих спостережень - через рік і більше на III-IV рівнях дії статинів.

\section{Література}

1. Аникеева Т.В. Изменение содержания микроэлементов в организме больных с патологией сердца / Т.В. Аникеева, О.В. Синяченко, Л.Ю. Максимова // Вестн. неотлож. и восстановит. мед. - 2008. - Т. 9, № 4. - C. 578-583.

2. Башкірова Л. Біологічна роль деяких есенційних макро- та мікроелементів (огляд) / Л. Башкірова, А. Руденко // Ліки України. - 2004. - № 10. - С. 59-65.

3. Горбачев А.Л. Особенности микроэлементного статуса пожилых и старых людей / А.Л. Горбачев, А.В. Скальный // Микроэлементы в медицине. 2009. - T. 10, № 1-2. - С. 17-26.

4. Дослідження вмісту мікроелементів (Си, $\mathrm{Zn}, \mathrm{Fe})$ у рові хворих на IXC та мігрень, що асоційовані з гелібактеріозом / П.О. Колесник, Т.В. Созонюк, О.В. Ариповський [та ін.] // Сімейна мед. - 2010. - № 1. - С. 95-99.

5. Шкала Л.В. Мікроелементи: біологічна роль в організмі людини / Шкала Л.В. // Гал. лікар. вісник. - 2003. T. 10, № 4. - С. 125-127.

6. Макро-и микроелементы крови у пациентов пожилого и старческого возраста, страдающих хронической ишемической болезнью сердца / Т.М. Юрина, Т.А. Купріянова, О.И. Лямина [и др.] // Клин. мед. 2005. - № 1. - C. 20-24

7. Trace element status $(\mathrm{Se} \mathrm{Zn} \mathrm{Cu})$ in heart failu / F. Kozar, I. Sahin, C. Tazkapan [et al.] // Anad Kardiyol. Derg. 2006. - Vol. 6, № 3. - P. 216-220.

8. Acute cardiopulmonary alterations induced by fine particulate matter of San Paulo, Brazil / D.H. Rivero, S.R Soares, G. Lorenzi-Filho [et al.] // Toxicol. Sci. 2005. - Vol. 85, № 2. - P. 898-905.

9. Hughes S. The effect of zinc supplementation in humans on plasma lipids, antioxidant status and thrombogenesis / S. Hughes, S. Samman. // Am. Coll. Nutr. - 2006. Vol. 25, № 4. - P. 285-291.

\section{ВЛИЯНИЕ ДЛИТЕЛЬНОЙ ТЕРАПИИ СТАТИНАМИ НА МИКРОЭЛЕМЕНТНЫЙ ОБМЕН У БОЛЬНЫХ ИШЕМИЧЕСКОЙ БОЛЕЗНЬЮ СЕРДЦА}

\section{В.И. Клименко}

Резюме. В 66 больных стабильной стенокардией напряжения изучены изменения микроэлементного обмена и показатели инструментальных методов обследования в зависимости от уровня в крови общего холестерина и во время длительной липидоснижающей терапии. Показаны неоднозначные изменения микроэлементного обмена, показателей внутрисердечной гемодинамики и толерантности к физической нагрузке на фоне терапии статинами.

Ключевые слова: ишемическая болезнь сердца, статины, микроэлементы.

\section{INFLUENCE OF LONG LIPID LOWERING THERAPY ON THE MICROELEMENT EXCHANGE IN PATIENTS WITH CORONARY ARTERY DISEASE}

\section{V.I. Klymenko}

Abstract. In 66 patients with stable angina tension changes of microelement exchange and instrumental examination findings depending on the general cholesterol level in the blood and during the protracted lipid lowering therapy have been studied. The ambiguous changes of microelement exchange, of intracardiac haemodynamics indices and tolerance to an exertion while taking statins have been shown.

Key words: coronary artery disease, statins, microelements.

SHEI " National Medical University" (Ivano-Frankivsk)

Рецензент - д. мед. н. Т.О. Ілащук

Buk. Med. Herald. - 2014. - Vol. 18, № 1 (69). - P. 51-53

Надійшла до редакції 03.12.2013 року

(C) B.I. Клименко, 2014 